\title{
PROCESSO DE CONSTRUÇÃO DO PERFIL DOCENTE: RELATOS DE ESTUDANTES DE LICENCIATURA EM PEDAGOGIA
}

\section{ARTIGO ORIGINAL}

NASCIMENTO, Ana Cláudia do ${ }^{1}$

NASCIMENTO, Ana Cláudia do. Processo de construção do perfil docente: Relatos de estudantes de licenciatura em pedagogia. Revista Científica Multidisciplinar Núcleo do Conhecimento. Ano 05, Ed. 08, Vol. 03, pp. 05-30. Agosto de ISSN: 2448-0959,

Link de acesso: https://www.nucleodoconhecimento.com.br/educacao/construcao-do-perfil

\section{RESUMO}

Com o constante avanço científico-tecnológico-social, observa-se a necessidade de novas práticas sobre a forma de ensinar e aprender, principalmente pelo o fato de que a educação precisa estar contextualizada com vivência dos estudantes. Nesse sentido, compreender a importância do processo de formação docente é fundamental e urgente. Desse modo, objetivou-se na pesquisa investigar a visão dos estudantes do curso de pedagogia sobre o processo de construção do perfil docente, no intuito de compreender como a grade curricular influência no desenvolvido da docência. Para estabelecimento da proposta, foi utilizado um questionário, contendo 11 perguntas objetivas e subjetivas sobre o tema abordado. A coleta de dados foi realizada a partir do método Survey, e as respostas atribuídas pelos estudantes durante a coleta de dados foram analisadas qualitativamente. No total da pesquisa foram entrevistados 29 graduandos do curso de Licenciatura em Pedagogia. Foi observado a partir do recorte geral das respostas dos discentes que algumas destacam os pontos positivos, afirmando que o curso com seus amplos aspectos, auxiliam na formação crítica dos

\footnotetext{
${ }^{1}$ Mestranda em Ciências da Educação. Especialista em Neuropsicologia, pelo instituto de Neuropsicologia Aplicada - INAP. Bacharel em Psicologia, pela Faculdade de Ciências humanas de Olinda - FACHO.
} 
profissionais. Alguns estudantes destacaram o fato de que, na maioria das vezes, durante o curso é visto muito teoria, ao invés de prática. Através dos resultados foi verificada a importância de discutir conteúdos e estruturas curriculares voltados à formação docente, assim como ter uma melhor concepção do contexto de formação docente por parte dos estudantes do curso de licenciatura.

Palavras-chave: Ensino-aprendizagem, construção do saber, docência.

\section{INTRODUÇÃO}

Diante da necessidade de práticas sobre a forma de ensinar e aprender, estão cada vez mais discutidas dentro do universo da educação estas práticas, tendo grande enfoque a vivencia dos estudantes, mediante o meio social. Neste cenário, a ação do professor além de estar fundamentado em fins pedagógicos, precisa ser trabalhada de modo a dar significado aquilo que se é estudado.

Entretanto, sabe-se que a aprendizagem durante o processo de formação docente, em grande parte, é adquirida por meio das disciplinas, que por sua vez, acabam se distanciando e/ou aproximando o futuro professor da realidade escolar no qual poderá se deparar.

Nesse sentido, os desafios de uma prática docente podem ser executados a partir de uma nova forma de ensinar, assim como aprender a aprender. A docência, por sua vez, não está restrita apenas ao domínio de conteúdos específicos, mas associativa destes com o "para que" e "como fazer".

De acordo com Fernandes, Freitas e Carneiro (2019) uma questão que sempre surge quando se trata de didática no Ensino Superior é: "qual a importância que os docentes atribuem à didática em sua atividade profissional?" Sabe-se que por meio da didática a metodologia do docente é moldada, por consequência, seu perfil docente pode ser traçado ao longo de sua jornada acadêmica, em especial, na licenciatura.

Entender a importância do processo de formação docente é fundamental e urgente. Segundo Freiberger e Berbel (2010) pensar o desfio de educar, em especial no ensino 
infantil e fundamental, tem-se a necessidade que a educação contemple a articulação entre teoria e prática, ambas voltadas para a (re)construção de conhecimentos.

Em relação ao curso, a oferta do curso pedagogia nas IES (instituições de ensino superior) brasileiras teve crescimento impulsionado por meio da Lei de Diretrizes e Bases de 1996, que previu em seu texto legal a formação do pedagogo através de curso superior, ocorrendo então uma expansão em todo território brasileiro.

Desse modo, objetivou-se Investigar a visão dos estudantes do curso de pedagogia sobre o processo de construção do perfil docente. No sentido de tentar compreender como a grade curricular influência no desenvolvido da docência, no que se referem a disciplinas, estágios e projetos, assim como analisar a percepção dos estudantes sobre como são articuladas e associadas à teoria e a prática no presente curso.

\section{METODOLOGIA}

\subsection{DESCRIÇÃO DA ÁREA DE ESTUDO}

A pesquisa foi situada na região de Pernambuco, um dos estados do nordeste do Brasil, apresentando uma estimativa populacional em 2019 de 9.557.071 habitantes.

\subsection{PROCEDIMENTOS PARA REALIZAR A PESQUISA}

No intuito de identificar a construção do perfil docente a partir do olhar de estudantes de pedagogia, utilizou-se um questionário, contendo 11 perguntas objetivas e subjetivas sobre o tema abordado.

Para coleta de dados, foi utilizado o método Survey, que consiste na obtenção de dados ou informações sobre características, ações ou opiniões de grupos de pessoas. Vale destacar que, nesse tipo de pesquisa, o respondente não é identificável, nesse caso, o sigilo é garantido. 


\subsection{ANÁLISE E ESTRUTURAÇÃO DOS DADOS}

As respostas atribuídas pelos estudantes durante a coleta de dados foram analisadas qualitativamente. De acordo com May (2004, p. 146):

Ao avaliar esses diferentes métodos, devemos prestar atenção, [...], não tanto aos métodos relativos a uma divisão quantitativa-qualitativa da pesquisa social - como se uma destas produzisse automaticamente uma verdade melhor do que a outra -, mas aos seus pontos fortes e fragilidades na produção do conhecimento social. Para tanto é necessário um entendimento de seus objetivos e da prática.

De acordo com Flick (2004) a convergência que se encontra entre os métodos quantitativos e qualitativos geram mais confiabilidade aos resultados encontrados.

$\mathrm{Na}$ coleta, as questões do formulário foram identificadas por códigos. Sendo utilizada letra "Q" (questão) seguido de um número sequencial, por exemplo: Q1 - Questão 1. A identificação dos participantes seguiu o mesmo padrão, com a utilização da letra "P" (pessoa), por exemplo: P1 - pessoa 1. Para representação e facilidade da leitura foi feita uma amostragem de cada resposta.

\subsection{PROCEDIMENTOS ÉTICOS}

Mediante a participação, foi assinado o Termo de Consentimento Livre e Esclarecido (TCLE) para que analisassem as finalidades descritas da proposta. O TCLE continha informações específicas sobre a pesquisa, bem como assegurando o sigilo das informações pessoais dos participantes.

\section{RESULTADOS E DISCUSSÃO}

No total da pesquisa, foram entrevistados 29 graduandos do curso de Licenciatura em Pedagogia. No que se refere à idade dos participantes Q1, teve-se um número maior entre 20 e 25 anos, com 11 participantes, apresentando total de 37,93\%, seguido de idades de 26 e 30 anos, com sete participantes, representando 24,94\% (Figura 1). 
Figura 1. Média da idade dos participantes da pesquisa

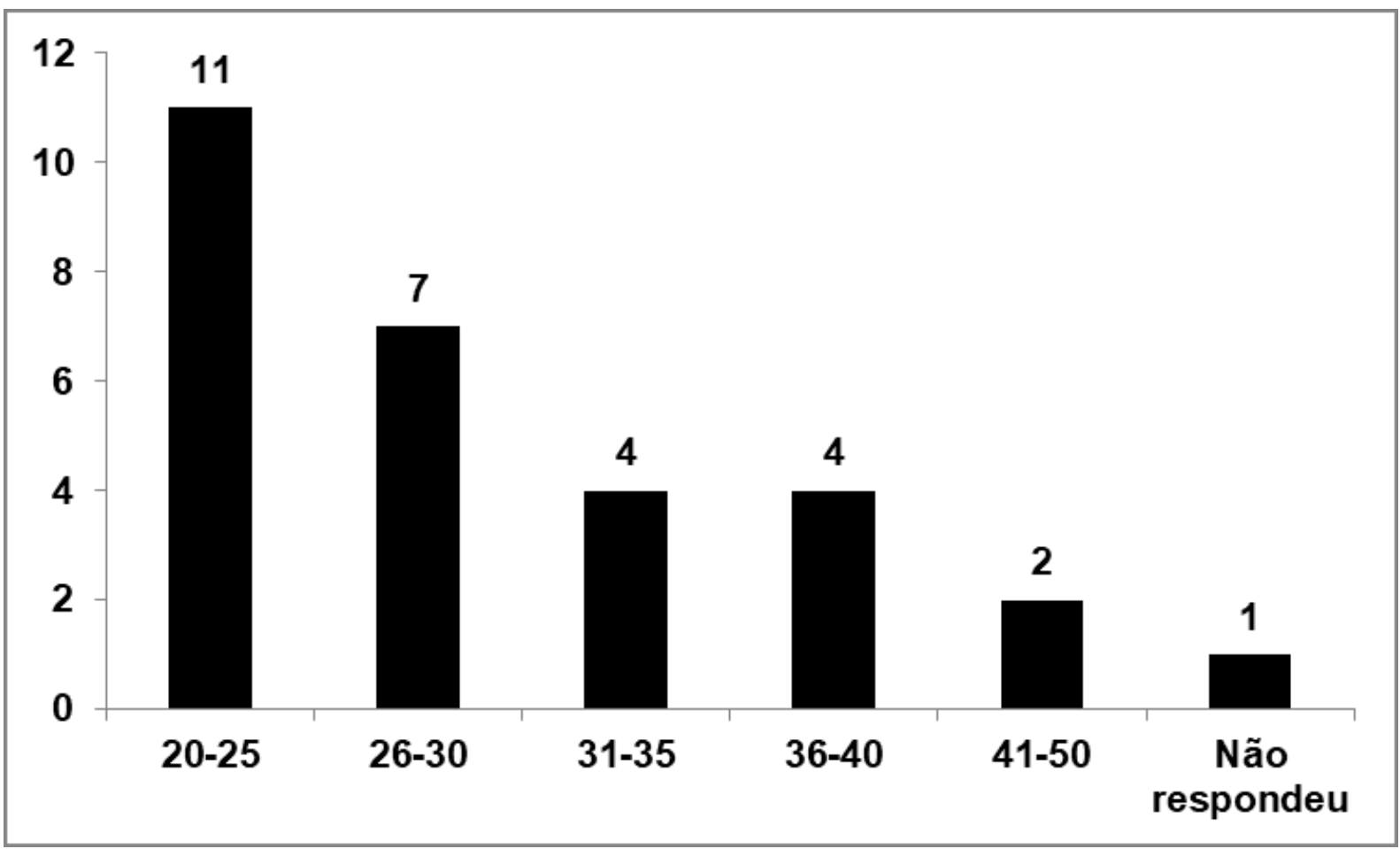

Observa-se que se tem uma tendência de graduandos que se encontram na faixa dos vinte anos, no qual pode ter se dado em função do aumento do número de vagas e acesso a universidade. Desse modo, ao saírem do ensino médio, grande parte dos estudantes, já se destinam a graduação.

A partir Q2, dentre os participantes, foi identificado um total maior de participantes do sexo feminino com 25 pessoas, representando $86,21 \%$, em relação à presença masculino com 4 participantes, tendo $13,79 \%$ do total (Figura 2). 
Figura 2. Distribuição do total de participantes da pesquisa por sexo

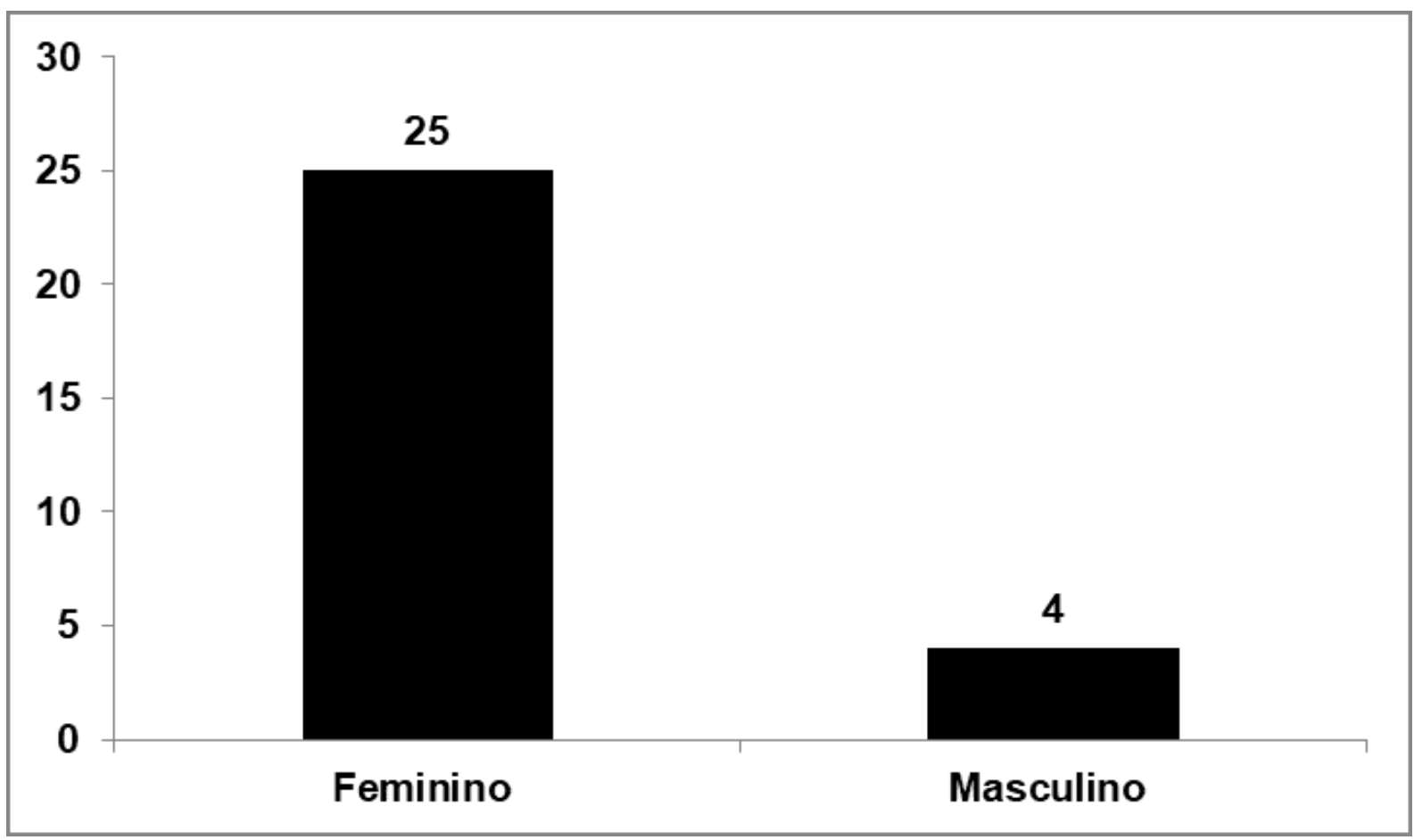

Fonte: Autoria própria, 2019.

Segundo Silva (2011) que aborda o processo de feminização do magistério, defende o autor que este aspecto de feminização ocorreu em função da transferência dos predicados do lar - "cuidado, carinho, amor, dedicação, vocação - para esse campo". Segundo a autora, essa atividade é considerada uma continuidade da educação primária do lar e esses atributos vão constituindo o feminino. E, segundo dados da Datafolha (2018), a presença de mulheres no curso de Pedagogia é maciça, totalizam $98 \%$ das salas de aula, estando de acordo com os dados observados na presente pesquisa.

Com relação ao universo geográfico da pesquisa, Q3, quatro cidades foram citadas, sendo a maioria dos participantes do Recife, com 24 participantes, representando $82,76 \%$ do total (Figura 3). 
Figura 3. Distribuição do total de participantes da pesquisa por cidade

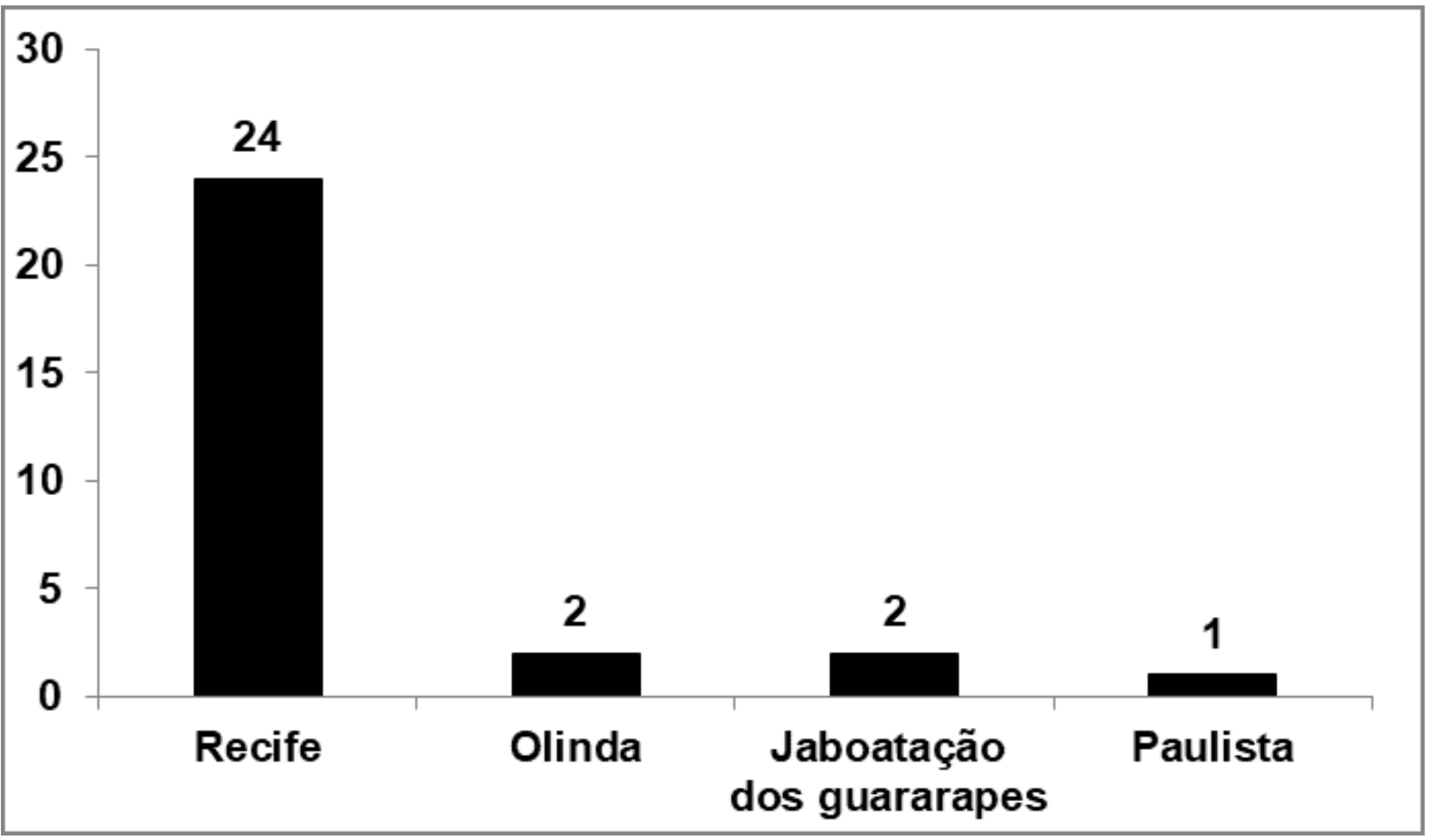

Fonte: Autoria própria, 2019.

Sobre o período do curso dos estudantes participantes da presente pesquisa, Q4, a maioria estava no sexto período representando $41,4 \%$, seguido dos que estavam no quinto período com $37,93 \%$ (Figura 4). 
Figura 4. Percentual do período do curso, nos quais os participantes da pesquisa estavam cursando no momento

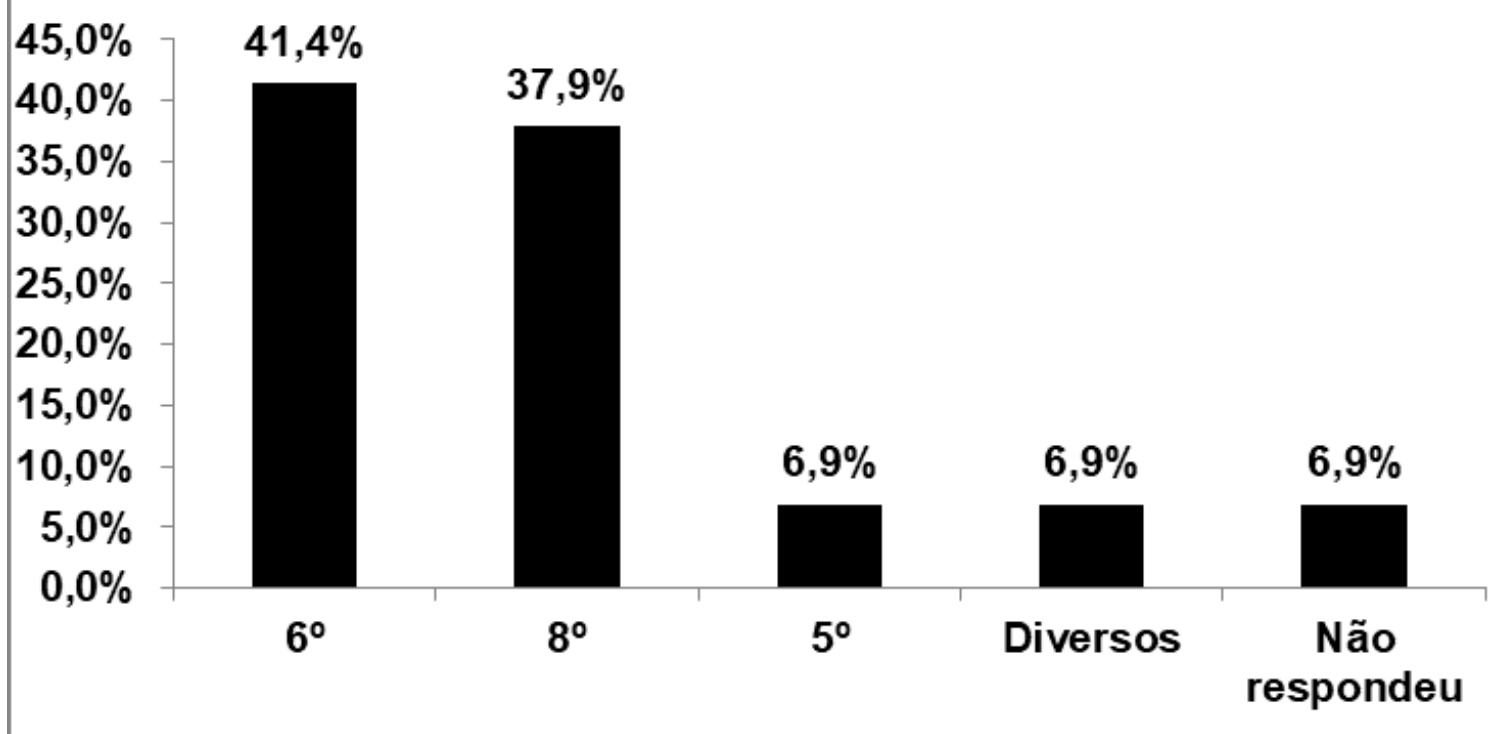

Fonte: Autoria própria, 2019.

Quando questionados sobre como o curso influência através das disciplinas/estágios/projetos e outros na formação do professor, Q5, foi obtido respostas variadas, destacando algumas, sendo estas:

P1: "Influencia bem: mas poderia ser melhor, penso em forma mais prática e mais inclui os alunos poderiam ser mais livres trazendo o conteúdo de uma forma mais livre e mais diversa".

P2: "O curso é muito teórico. É um curso bom, mas se distância muito da parte prática da vida de um professor".

P3: "Contribui com todo conhecimento teórico necessário para encarar os desafios de ser um professor. A prática acredito que só se dá quando o educando de pedagogia se depara com a sala de aula". 
P4: "As disciplinas e os estágios nos dão a oportunidade de conhecer e colocar em prática muitas coisas que iremos encontram na nossa escolha profissional".

P7: "Ajuda na construção dos conhecimentos teóricos e da realidade social, cultural, político e etc.".

P10: "O curso de pedagogia nos permite enxergar alguns pontos na educação que não entendemos antes dele. Cada disciplina tem a função teórica de nos ensinar como agir em determinada atuação. Os estágios nos proporcionam a experiência prática e a que mais ensina. Nada melhor que na prática para apropriar desse conhecimento".

P13: "Através das disciplinas podemos nos abastecer de referencial teórico, unido a diversas propostas dos professores construímos projetos que nos aproximam da realidade escolar e ampliamos nossas perspectivas e propostas de debates. E os estágios oportunizam a prática supervisionada".

P23: "O curso pedagogia é uma graduação que nos estimula a pensar criticamente nas diversas realidades, permitindo a idealização de mudanças de realidades, fazendo o profissional o ser capaz de transformar".

P24: "Influência muito na formação do conhecimento, da segurança, o que e como você deve usar os conteúdos. Sabemos que cada aluno é diferente do outro, usar estágios como aplicar em sala de aula".

P27: "Acredito que o contato com a sala de aula, os alunos, a vivência em si, acaba nos aproximando ou nos norteando daquilo que vivenciamos/viverei, futuramente e me dando uma noção se realmente é essa área que quero seguir".

Nota-se a partir das diferentes respostas, que algumas destacam os pontos positivos, visto que o curso com seus amplos aspectos auxiliam na formação crítica dos profissionais, assim como na construção docente. Entretanto, observa-se em algumas respostas o fato de trazer muita teoria, ao invés de prática. Sendo assim, embora importância enxergue a falta desde contato mais prático. 
Projetos extraclasses, assim como estágios é o momento em que o estudante tem oportunidade de utilizar-se dos conhecimentos adquiridos ao durante o percurso acadêmico.

Este processo de formação tem o objetivo de preparar o estagiário para executar atividades nas escolas, juntamente aos professores nas salas de aula, possibilitando uma avaliação e crítica, dificuldades que a rotina nas escolas, pode revelar. E, observado este pensando nas respostas dos estudantes, quando afirmam que de fato projetos/estágios e demais, auxiliam em sua formação (PIMENTA; LIMA, 2011).

Tais objetivos devem ser centrados em consolidar e articular as competências desenvolvidas ao longo de todo curso de formação, uma vez que é durante o estágio e demais exercício que promovam este contato direto com a prática, para que o licenciando possa vivenciar situações de efetivo fazer docente (BRASIL, 2015).

Ao perguntar o que eles pensam a respeito do processo da construção do saber enquanto professor em formação, quais suas ideias e inspirações, Q6, apesar de algumas abstenções na resposta, alguns responderam de forma interessante, podendo destacar algumas das respostas, tais como:

P3: "Minhas inspirações se afastam muito da forma tradicional que sempre tratamos o saber. Sempre que estudo ou me inspiro procuro muito biografias mais criativas lúdicas, construtivas".

P4: "O processo de construção do saber não é uma tarefa fácil cada indivíduo tem o seu tempo para aprender. O papel do professor nesse processo é de entender como o aluno constrói o conhecimento e ajuda-lo nessa etapa".

P6: "O processo de construção do saber deve ser longo de toda profissão participando de cursos, oficinas, e colocando sempre em prática as metodologias de acordo com cada série. Ideias e inovações em cima de trabalhos com o lúdico, criatividade".

P9: "Em nossa formação docente, na medida em que pagamos as disciplinas montamos um quebra-cabeça e demos sentido ao que é estudado. A partir dessas 
disciplinas encontramos a área a qual desejamos nos especializar. Eu particularmente me encontrei quando paguei a disciplina de psicomotricidade e pretendo me especializar na área".

P10: "Os conteúdos são bem extensos e muitas vezes não são bem trabalhados e assim precisamos sempre complementar dos cursos. $\mathrm{O}$ autor Paulo Freire é a minha inspiração".

P11: "Estar aberto e buscar conhecimento é uma prática inerente a atividade docente, portanto é necessário querer e ver disciplina na busca pelo conhecimento. Alguns professores, educadores e teóricos que conheci nesse processo".

P12: "O processo de construção é sempre inquietador nos mostrando sempre possibilidades diferentes diárias. Minhas ideias e inspirações são baseadas nas vivências e construções diárias".

P16: "É algo que se adquire todo dia, constantemente, não tem fim, cujas inspirações vêm através de pessoas sejam pedagogas ou não que conheci ou admiro onde sabem passar prazer e muita alegria para as crianças".

P19: "O processo de construção do saber é contínuo e mútuo, ocorre de forma interdisciplinar e integra aspectos sociais, culturais e políticos. Sobre este movimento, penso que antes de decidir ser professor, devemos estar comprometidos com impactos socais relevantes, comprometidos com o outro e o que se inspira é de fato a vontade de se oportunizar um lugar e meio de vida digno a todos".

P20: "O saber é algo em constante crescimento, "quanto mais sei, percebo que nada sei". Amo a citação de Mandela A educação é uma arma poderosa, que pode mudar o mundo, no entanto prefiro unir Mandela a Freire, pois acredito que a educação transforma, mas a educação transforma pessoas e as pessoas transformam o mundo. Resta apenas a preocupação e a responsabilidade em que mudanças vamos causar: positivas ou negativas". 
Observar-se nas respostas que a grande maioria trouxe à tona a questão do saber construindo, se afastando da ideia da aprendizagem tradicional, o que se nota que a tendência de fato do saber para uma aprendizagem significativa, e para tanto, construída por parte do professor e estudante. Destaca-se também o fato de os entrevistados citarem as disciplinas como ponto essencial nesse processo de construção docente de modo pessoal, como por exemplo, a P3 que cita o fato de ter se encontrado em determinada disciplina. Algumas respostas apareceram como inspiração docente, o autor Paulo Freire, no qual revolucionou o saber educacional com seu método, e de fato se tornou bastante importante no universo educativo.

Entre as respostas aparecem também à questão de a construção do saber ser um processo continuo, mas a importância de se conhecer professores, teóricos ao longo do percurso.

Segundo Cunha (2016) uma nova organização que se dá através da relação teoria/prática pode ser o indicador com maior frequência nas práticas pedagógicas, passando de um modo acadêmico tradicional, para a inclusão das relações socioafetivas como condição da aprendizagem significativa.

Tem-se ainda o fato de que a partir de algumas respostas foi observado o fato de que as próprias vivências dos estudantes promovem este pensamento construtivo de papel docente. E, neste sentido, Freire (1996) traz que:

[...] quanto mais me assumo como estou sendo e percebo a ou as razões de ser de porque estou sendo assim, mais me torno capaz de mudar, de promover-me, no caso, do estado de curiosidade ingênua para o de curiosidade epistemológica. Não é possível a assunção que o sujeito faz de si numa certa forma de estar sendo sem a disponibilidade para mudar. Para mudar e de cujo processo se faz necessariamente sujeito também. (FREIRE, 1996, p. 44).

De acordo com Zabalza (2004, p. 153), "[...] uma boa formação sobre os processos de ensino-aprendizagem servirá para elucidar e dar sentido à ação docente, contribuindo, assim, para sua melhora". 
Quando questionados em relação à ideia que os estudantes têm sobre a futura profissão, a sua importância e o impacto que a mesma apresenta na sociedade, Q7. Algumas das respostas foram:

P5: "Pretendo formar cidadãos críticos e que saibam lutar pelo direito que não the foi garantido. Espero que meus alunos alcancem profissões brilhantes".

P7: "Considero a profissão professor a mais nobre de todas e deveria ser muito valorizada pela sociedade. Pois uma nação sem educação de qualidade não tem um futuro prospero".

P8: "Extrema importância. Um impacto que se mantém por toda a vida, os ensinamentos passados de uma forma proveitosa e agradável para todos da turma. A pedagogia é para mestres dispostos a ensinar e aprender".

P15: "Entendo que os profissionais da educação são grandes engenheiros do conhecimento. Educam os homens, os libertam da ignorância e ideologicamente desvio que somos as chaves e os meios para a construção da sociedade que desejamos".

P16: "Espero um futuro com pessoas mais capacitadas, que desejam melhoria em sua vida e na vida de quem o rodeia, e espero causar um impacto positivo, de muito impacto positivo na vida dos educandos".

P22: "Insegurança, somos responsáveis por colaborar na formação de cidadãos, no qual vivemos em uma sociedade caótica. Na qual governadores e representante político tem medo, fazendo com que verbas para uma educação de qualidade seja cortada".

P25: "Algo que exige que sejamos constantes e autênticos, compromissados não apenas com a educação, mas com o ser humano. Na sociedade não sou uma superheroína com o quadro e o piloto, mas posso dá minha contribuição na formação de seres humanos melhores". 
P26: "Ser um professor que se preocupe com o aprendizado do aluno. Formar para ser um cidadão. Quando você gosta do que faz, valoriza e se preocupa com o outro, tudo fica mais fácil".

P28: "Mudar vidas de alguma forma".

Nota-se que as questões coadunam no que se refere à importância da profissão e que a partir da mesma encontrasse a possibilidade de mudanças no meio social, consequentemente apresentando alto impacto.

Sobre este aspecto, Rossato; Matos e Paula (2018) trazem que o reconhecimento das próprias experiências, uma busca constante da atualização do conhecimento, bem como consciência de sua ação profissional são fatos importantes a serem observados.

Na obra de Libâneo enxerga-se a Pedagogia, sendo um dos cursos de graduação mais democráticos, com suas diferenças e contribuições para um mundo melhor. Para o autor:

Temos diferentes cursos, diferentes níveis de qualidade, diferentes níveis de formação dos professores-formadores. Poucos cursos de formação profissional atingem os mais distantes municípios, compondo as culturais locais, criando um tipo de cidadão, ajudando as crianças a terem um rumo na vida, ampliando as possibilidades de conquistar a dignidade humana (LIBÂNEO, 2005).

Por outro lado, foi citada a questão de insegurança, e fatores semelhantes, como destacado na resposta da P22. Nesse sentido, o estudo de Hanushek; Rivkin, 2007 demonstra que a qualidade do ensino é um aspecto central para aumento da qualidade da escola, e que fatores como estrutura e investimento, apresentam papel preponderante na determinação do desempenho do professor e aluno.

Quando questionados acerca do processo de ensino-aprendizagem teórico ensinado e discutido em sala de aula se o mesmo se encontra diretamente relacionado com a realidade da sociedade atual, Q8 observou-se que $51,74 \%$ dos entrevistados falaram que sim, enquanto que 37,93\% afirmaram que não e 10,34\% afirmaram que em partes (Figura 5). 
Figura 5. Percentual das respostas quando questionados se o conhecimento teórico da sala de aula está relacionado com a realidade da sociedade atual

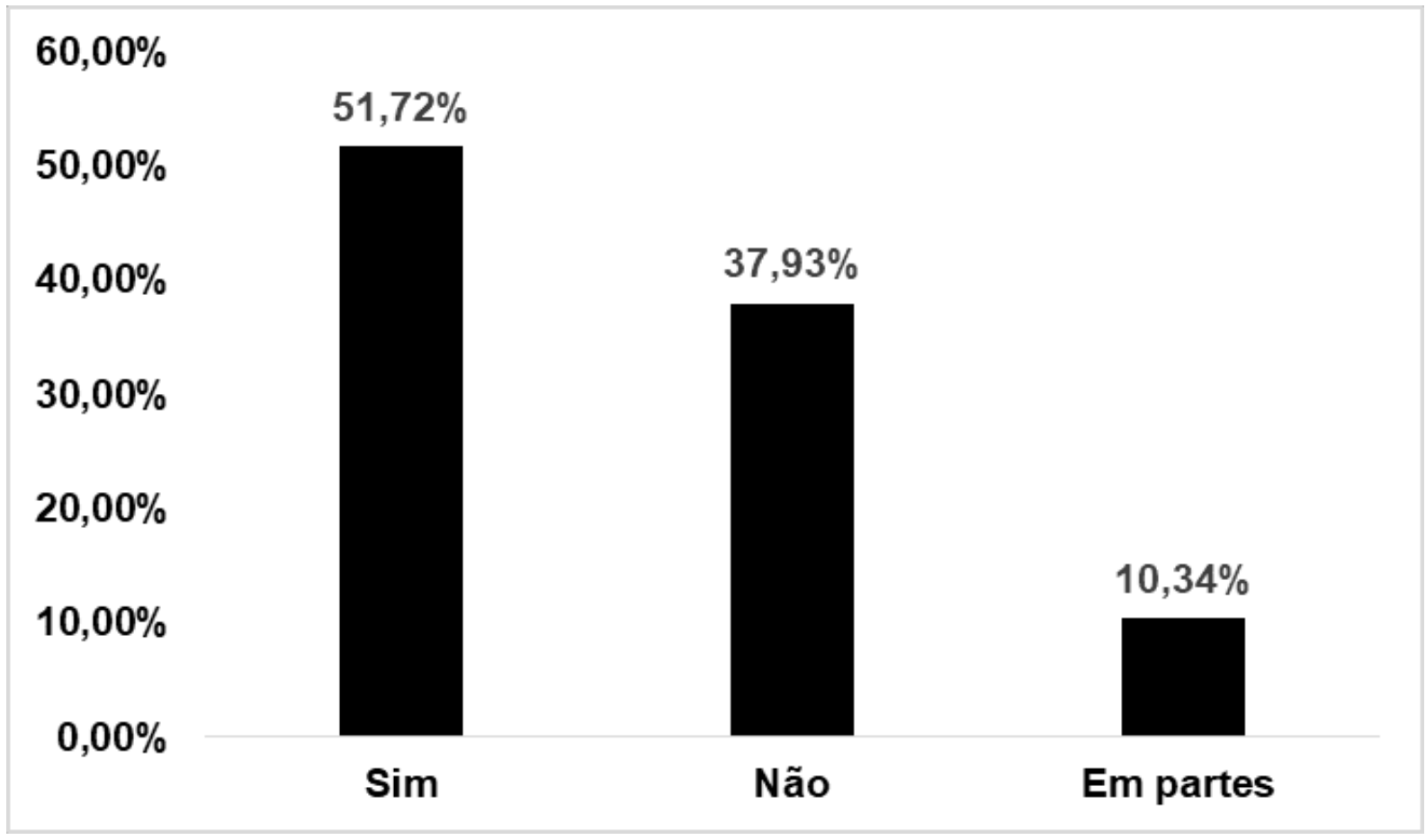

Fonte: Autoria própria, 2019.

Ao serem questionados sobre a justificativa da resposta, têm-se alguns destaques, sendo estas:

P1: "Não, é totalmente diferente a teoria e a prática".

P2: "Sim. Tratamos muito sobre a realidade".

P7: "Não, não tenho muito conhecimento sobre a prática, mas acredito de as duas estão bem distantes".

P9: "Sim, o ensino propõe assuntos que leva os alunos a questionamentos, sobretudo político social, cultural e outros".

P10: "Em parte, existem professores que contextualizam o conteúdo com a realidade atual da nossa sociedade". 
P14: "Não. Aprendemos muita teoria que na prática não é possível aplicar diretamente proporcional. A realidade as dificuldades em sala de aula são bem difícil”.

P23: "Sim. As referências teóricas abordadas ao longo do curso, foram todos cautelosamente selecionados a tratar aspectos que de fato são relevantes e condiz com os problemas vivenciados cotidianamente. Trabalhamos Piaget a Pedro Demo, dentre outros, como: Paulo Freire".

P26: "Sim. A tecnologia está aí pra todos. Com professores responsáveis, precisamos levar as informações. Isso está diretamente relacionado com tudo. Cuidar de tudo que você aprende e escuta".

P27: "Sim. Felizmente o ensino acadêmico tem levado mais em consideração a educação da realidade, e não aquela idealizada que o povo se vê na prática".

Nesse aspecto, os documentos legais que trazem, por meio do Conselho Nacional de Educação, em sua resolução que:

§ 1ํ A prática, na matriz curricular, não poderá ficar reduzida a um espaço isolado, que a restrinja ao estágio, desarticulado do restante do curso.

$\S 2^{\circ}$ A prática deverá estar presente desde o início do curso e permear toda a formação do professor.

$\S$ 3ํ№ interior das áreas ou das disciplinas que constituírem os componentes curriculares de formação, e não apenas nas disciplinas pedagógicas, todas terão sua dimensão prática (BRASIL, 2002).

Diante do exposto acerca da realidade da sociedade está de acordo com o que é estudado em sala de aula, nota-se que apesar de sua importância e presença em documento legal, ainda assim, alguns estudantes afirmaram que a mesma encontra desassociada, como no posicionamento da P1 e P14, por exemplo, percebendo que ainda falta buscar-se mais essa aproximação nos cursos de formação docente.

Outra resposta que merece destaque é a P26, ao trazer a tecnologia como parte desse processo. Neste sentido, Frizon et al. (2015) escreve que as tecnologias digitais estão 
em constantes crescimento e transformações, apresentando-se inúmeras possibilidades, estando estas de fato bem presentes no contexto educativo.

Quando questionados sobre como se constrói o conhecimento, Q9 tem-se como destaque as seguintes respostas:

P5: "É um processo em que cada pessoa tem seu tempo de construir. Dia após dia ele é construído".

P7: "Com a participação de todos, sejam eles educadores e alunos. Todos têm a capacidade de ensinar e aprender".

P9: "O conhecimento se constrói a partir de abertura, da participação do indivíduo no meio social das várias possibilidades de formação e de um processo gradativo".

P11: "Em nosso dia a dia não necessariamente dentro da sala de aula, através da aprendizagem significativa".

P12: "O conhecimento se constrói através da convivência com o outro, na troca de experiências. Em sala de aula, por exemplo, existe uma troca entre professor e aluno, onde o professor através do conhecimento prévio da criança da sentido ao que é estudado".

P13: "Através da experiência, problematização e investigando".

P15: "É um processo de construção, que envolve entendimento, discussão, vivência, significação e continua busca".

P16: "O conhecimento é construído do dia a dia, levando sempre me consideração o conhecimento empírico de cada indivíduo".

P23: "O conhecimento ele é construído de forma empírica ou científica. Porém, o conhecimento só se desenvolve coletivamente". 
P24: "O conhecimento se dar de várias formas, através de debate, roda de conversa, com o estágio, a intervenção com os alunos".

P27: "O conhecimento é construído nas nossas relações com as pessoas e com o mundo, atribuindo cada vez mais significado e conceitos com as coisas que entremos em contato".

P29: "Acho que cada criança tem um tempo para aprender, todas em tempo diferentes, então envolve muitas coisas. Experiências, o meio social, a relação que a criança tem com a cultura e sem falar da aprendizagem em sala com os colegas e professores (como mediador)".

A partir das respostas é possível observar que foram citadas várias formas de aprendizagem, mas que são interconectadas entre si, como por exemplo, o fato da construção do conhecimento se dá de modo participativo, como citado pela P7 e P9. Ocorreu também um número maior de respostas que trazem que o conhecimento é construído com base na vivência pessoal, não apenas em sala de aula, porém também por meio de experiências, convívio social, e os dados estão de acordo com o que diz na literatura, quando se trata da construção do saber, sendo o estudante o principal responsável por seu aprendizado.

De acordo com Piaget, a aprendizagem é promovida através da experiência que a criança adquirindo. Tendo em mente o fato de que a afetividade e a interação social também contribuem diretamente para o aprendizado do estudante (MARTINS; MOURA; BERNARDO, 2018).

Piaget define assimilação como:

Uma integração às estruturas prévias, que podem permanecer invariáveis ou são mais ou menos modificadas por esta própria integração, umas sem descontinuidade com o estado prudente, isto é, sem serem destruídas, mas simplesmente acomodando-se à nova situação. (PIAGET, 1996, p. 13). 
Segundo Freire, educador e educando são sujeitos de um processo em que crescem juntos, devido à "[...] ninguém educa ninguém, ninguém se educa. Os homens se educam entre si mediatizados pelo o mundo". (FREIRE, 1974, p. 63).

Além disso, apesar de os alunos apresentarem uma bagagem de experiências, é por meio da relação estabelecida entre professor e estudante que se promove conhecimento (MARTINS; MOURA; BERNARDO, 2018). E, este fato também pode ser levado em conta quando se trata da construção docente, visto que os discentes em formação trazem consigo suas crenças, experiências, vivências e isso faz parte de sua identidade, que ao agregar a bagagem e vivência acadêmica, tem-se no somatório o ser docente.

Segundo Maccariello:

Uma prática pedagógica desvinculada do contexto social tende a ser uma prática tecnicista, abstrata alienada e alienante, porque não está referida à totalidade, na qual os fenômenos e fatos sociais interagem $e$ que podem ser compreendidos, na sua essência quando se estabelecem as suas interações de modo global e a sua dimensão histórica. (MACCARIELLO, 2003, p. 84).

Observa-se também que a partir do auxílio de atividades realizadas no meio acadêmico como parte dessa construção, como foi citado pela P24, bem como pela associação entre o conhecimento empírico e o cientifico, a P23.

Ao indagados sobre quais pontos os participantes poderiam propor como melhorias no ensino, em especial no curso de pedagogia, que pudesse auxiliar na construção do saber e perfil docente, Q10. Destaca-se:

P4: "Aulas mais práticas. Precisamos aproximar teoria e prática".

P8: "Melhorias em dar ênfase e mais visão, e dedicação dos estudantes em sala. Melhorias no foco nas disciplinas de inclusão".

P9: "O tempo para se apropriar dos assuntos abordados, como também um período maior para as disciplinas". 
P10: "Ter disciplinas com mais prática. Enquanto aprendemos a teoria que seja na prática”.

P11: "Mais aulas práticas, pois, nada melhor do que vivenciar. Na prática adquirimos mais conhecimento do que apenas na teoria".

P12: "Trabalhar por meio de estudos de casos e problematização".

P15: "Uma prática mais voltada para a realidade, aulas mais voltadas para a formação de um bom profissional. Proporcionando um interesse maior por parte dos alunos".

P16: "Mais cursos de formação. Palestras".

P25: "Estágio em campo, junto com seu professor da disciplina usar conteúdos dado em sala de aula. Professor e estágio deveriam andar mais juntos. Juntos eles fazem a diferença e completa tudo em prol do aluno".

P27: "Acho que o curso de formação é uma coisa básica, a pós e o mestrado são uma boa oportunidade para focar".

Através das respostas se observa a maioria citando o fato de ter mais aulas práticas, podem auxiliar no aspecto de se dá mais sentido a construção do perfil docente, assim como nota-se novamente a importância das disciplinas e estágios, entre as respostas, como cita a P9 e P25.

Outro fato destacado são os estágios, que promovem o contato com a realidade escolar, sendo significativos para a futura profissão de professor. Esse contato direto com o contexto escolar, gera a ampliação de sua reflexão, "construção e/ou desconstrução das suas expectativas sobre a profissão do ser professor" (NOBRE; MORAES, 2015).

Os participantes relataram também outros pontos, como, por exemplo, formação continuada, por meio de cursos de capacitação citado pela P16 e P27. Outra resposta interessante foi a da P12, ao citar "estudos de casos e problematização". Reul et al. (2016) relata que o uso da problematização como forma de ensino indicado quando 
os assuntos ou temas a serem abordados estão correlacionados com a vida em sociedade, tendo uma demonstração de problemas e estimulando a resolução dos mesmos pelos alunos.

Outra resposta interessante foi à dada pela P8 ao trazer como ponto relevante à dedicação dos estudantes, pois ao entender o fato de que a aprendizagem é construída, cada indivíduo tem uma parte de responsabilidade no processo, sendo este resultado da sua dedicação em buscar o aprender, bem com o aprender a aprender, na busca de uma aprendizagem que dê sentido e que ajude na sua construção docente.

Por fim, quando indagados sobre as suas perspectivas para o futuro, após a conclusão do curso e sobre o ensino, em geral, observou-se que a maioria respondeu sobre suas realizações pessoas, assim como alguns pontos da educação, Q11, sendo algumas das respostas:

P2: "Ter um salário justo. Uma escola ótima para trabalhar que o professor seja reconhecido como professor que eu tenha mais vez na escola mais capacitação nas escolas".

P3: "Poder transformar pessoas com o poder da educação, creio em uma educação transformadora".

P4: "Lecionar e continuar estudando".

P5: "Conseguir um bom emprego, concurso de preferência e continuar estudante outra licenciatura para lecionar da educação infantil ao ensino médio".

P7: "O curso de pedagogia possibilita muitas possibilidades. Mas por ter pouca prática acredito que não serem um diferencial no mercado".

P8: "Me tornar uma profissional competente, dentro de todas eu quero todas necessidades dos alunos na sala de aula, ter diversificada, sabendo dominar as metodologias de ensino". 
P9: "Continuar com a formação permanente e poder atuar e colaborar com o processo formativo daqueles que precisam, não só no espaço escolar, mas em outros espaços".

P11: "Atuar na área e realizar trabalhos sociais".

P12: "Atuar na minha área desejada e pôr em prática tudo aquilo que aprendi em minha vida acadêmica".

P14: "Quero trabalhar na área de gestão, pois não me identifico com a sala de aula".

P15: "Atuação na área, pois graduação é busca pelas áreas do conhecimento que mais me agradam e fazer concursos públicos na educação".

P16: "Um mercado de trabalho mais amplo de oportunidades para os futuros recémsaídos das faculdades".

P17: "Pretendo passar o que eu aprendi dentro da faculdade para as crianças e poder fazer a diferença na vida deles de alguma forma".

P18: "Após a conclusão o que espero é poder trabalhar numa instituição séria, onde eu possa desenvolver tudo o que pode aprender na caminhada da graduação. Me qualificado cada vez mais".

P21: "Que melhore esta política que os professores sejam mais reconhecidos e que surjam muitos concursos para essa área da pedagogia".

P23: "Após a conclusão da graduação vou dar continuidade com a pós de educação especial, e sobre o ensino, sei que ainda falta muito para alcançarmos a idade, mas que possamos fazer nossa parte, semear e emanar o que de fato acreditamos ser necessário para um mundo mais justo".

P24: "Minhas expectativas são as melhores. Pretendo me aprimorar em alguma área, depois estudar para concurso, tentar pôr em prática e fazer projeto social para trabalhar com as crianças do meu bairro". 
P25: "Infelizmente, não são boas as expectativas, diante da atual realidade que nos encontramos onde a educação tornou-se um negócio".

P27: "Que eu possa cada vez mais me aprofundar na área que eu gosto, a fim de me tornar uma profissional melhor".

P28: "Investir cada vez mais na área".

P29: "Bem, minha vontade é fazer mestrado na área da inclusão, para ser mais clara, em LIBRAS. Espero ter melhorias na classe e oportunidades. Espero atuar com surdos e torcendo para melhorias no ensino geral, inclusive, na educação inclusiva".

Destaca-se o fato de nas respostas aparecerem, melhores salários, mais valorização na área, assim como mais oportunidade. Nesse sentido, Ens et al. (2019) afirma que entre as inseguranças encontradas no mercado de trabalho docente é a questão da sua valorização, sendo predominantes. Por este fato, algumas pessoas tornam-se, muitas vezes, desmotivadas, como ressalta a P25. O sentido da valorização do magistério é expresso na Resolução CNE/CP n. 2, de $1^{\circ}$ de julho de 2015, parágrafo terceiro, do artigo 18:

[...] A valorização do magistério e dos demais profissionais da educação deve ser entendida como uma dimensão constitutiva e constituinte de sua formação inicial e continuada, incluindo, entre outros, a garantia de construção, definição coletiva e aprovação de planos de carreira e salário, com condições que assegurem jornada de trabalho com dedicação exclusiva ou tempo integral a ser cumprida em um único estabelecimento de ensino e destinação de 1/3 (um terço) da carga horária de trabalho a outras atividades pedagógicas inerentes ao exercício do magistério (BRASIL, 2015).

Do total de 29 participantes que responderam o questionário contendo 11 perguntas, 19 respostas foram identificas em branco, distribuídas entre seis questões, das quais a pergunta seis foi a de maior percentual de respostas em branco, com $31,58 \%$, seguido das questões 10 e 11, com 21,05\%, respectivamente (Figura 6). 
Figura 6. Percentual de questões não respondidas

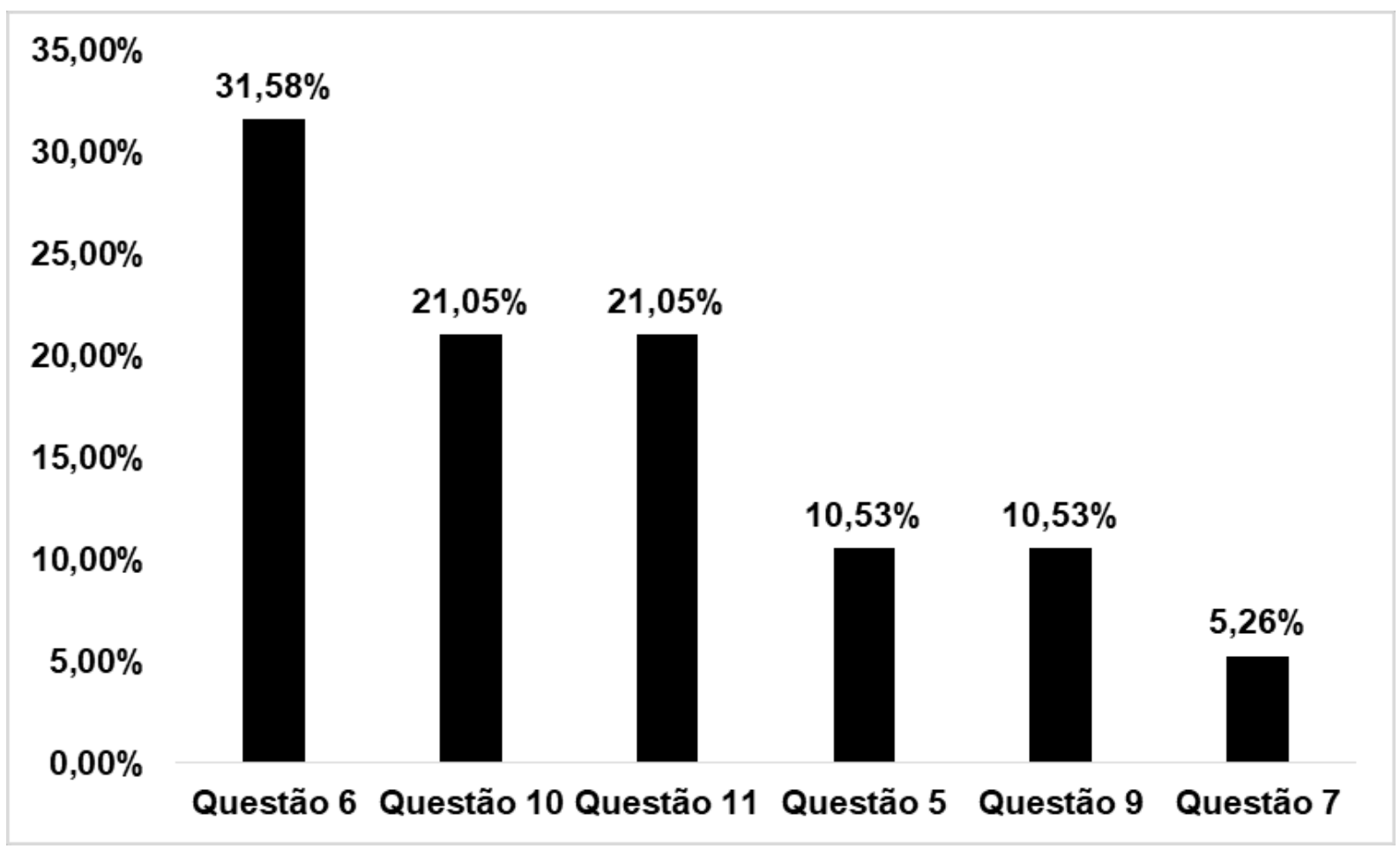

Fonte: Autoria própria, 2019.

A Q6 com maior percentual de pessoas que a deixaram em branco, foram referentes ao que os estudantes pensam a respeito do processo da construção do saber enquanto professor em formação. Entretanto, o fato pode ser explicado em função do fato de que o maior número de pessoas que participaram da pesquisa está cursando períodos considerados intermediário, ou seja, aproximadamente $50 \%$, onde não se tem o total de abrangência que o curso fornece. Sendo assim, ainda existem muitos pontos a serem vistos, discutidos e trabalhados. O mesmo vale para Q10 e Q11, visto que alguns não a responderam, podendo ir por estes aspectos supracitados, ou até mesmo o fator idade, visto que a maioria dos participantes está numa média equivalente aos vinte 20 a 25 anos.

\section{CONSIDERAÇÕES FINAIS}

Observou-se através dos resultados a importância de se discutir conteúdos voltados à formação docente, assim como ter uma melhor concepção por parte dos estudantes 
do curso de licenciatura. E, por meio dos relatos verificou-se que alguns, apesar de dificuldades em algumas respostas, afirmaram que a grade curricular dos cursos de formação auxilia de fato na formação da identidade docente. Entretanto, existe uma necessidade maior de práticas voltadas a realidade escolar, já que algumas vezes, a teoria torna-se mais presente.

Diante dos fatos, se tem a importância de estudos como estes, por se tratar de um tema tão relevante que a formação docente, em especial, nos cursos de licenciatura em pedagogia, onde os futuros professores atuarão diretamente com a formação inicial. Os resultados fornecem dados que dão subsídios para outros estudos da área de educação e afins.

\section{REFERÊNCIAS}

BRASIL, Lei da Diretrizes e Bases da Educação Nacional. No. 9394, de 20 de Dezembro, 1996.

BRASIL. Conselho Nacional de Educação. Define as Diretrizes Curriculares Nacionais para a formação inicial em nível superior (cursos de licenciatura, cursos de formação pedagógica para graduados e cursos de segunda licenciatura) e para a formação continuada. Resolução CNE/CP n. 02/2015, de $1^{\text {o }}$ de julho de 2015. Brasília, Diário Oficial [da] República Federativa do Brasil, seção 1, n. 124, p. 8-12, 02 de julho de 2015. Disponível em: $<$ http://portal.mec.gov.br/docman/agosto-2017-pdf/70431-res-cne-cp-002-03072015pdf/file> Acesso em 12 de dezembro de 2019.

BRASIL. Ministério da Educação. Parecer CNE/CP № 05/2005, de 13 de dezembro de 2005. Conselho Nacional de Educação - Conselho Pleno, Brasília, 2005.

BRASIL. Resolução CNE/CP 02. Institui a duração e a carga horária dos cursos de Licenciatura, de graduação plena, de formação de professores da Educação Básica em nível superior. Brasília, 4 mar. 2002d. Seção 1, p. 9. 2002b. 
CUNHA, M. I. Inovações na educação superior: impactos na prática pedagógica e nos saberes da docência. Em Aberto, v. 29, n. 97, p. 87-101, 2016.

ENSL, R. T.; RIBASLL, M. S.; OLIVEIRA, J. L.; TRINDADE, R. Valorização do professor: prioridade política, tensão ou incerteza? Cad. Pesqui. v.49, n. 172, p. 260283, 2019.

FERNANDES, A. B.; FREITAS, M. C. C.; CARNEIRO, S. N. V. Didática no ensino superior: possibilidades e práticas. Momento: diálogos em educação, v. 28, n. 1, p. 262-277, 2019.

FLICK, U. Uma introdução à pesquisa qualitativa. 2. ed. Porto Alegre: Bookman, 2004.

FREIBERGER, R. M.; BERBEL, N. A. N. A importância da pesquisa como princípio educativo na atuação pedagógica de professores de educação infantil e ensino fundamental. Cadernos de Educação, v. 37, p. 207-245, 2010.

FREIRE, P. Pedagogia da autonomia: Saberes necessários a prática educativa. São Paulo: Paz e Terra, 1996.

FREIRE, P. Pedagogia do oprimido. Rio de Janeiro: Paz e Terra, 1974.

FRIZON, V.; RICHIT, A. Compreensões sobre Tecnologias Digitais em Educação: uma análise sobre as Diretrizes de Ensino de Concórdia-SC. Quaestio, v. 19, n. 2, p. 471-490, 2017.

HANUSHEK, E. A.; RIVKIN, S. G. Pay, working conditions and teacher quality. Future of Children, v. 17, n. 1, p. 68-86, 2007.

LIBÂNEO, J. C. P. Pedagogia e Pedagogos, para quê? 4ª Ed. São Paulo: Cortez, 2001.

Pontos Críticos dos atuais cursos de Pedagogia. Revista Presença Pedagógica, v.11, n. 65, p. 52-63, 2005. 
MACCARIELLO, M. do C. A Construção coletiva da escola: consciência, representação e prática social. Supervisão e orientação educacional: perspectivas de integração na escola, v. 3, p. 31-68, 2003.

MARTINS, E. D.; MOURA, A. A.; BERNARDO, A. A. O processo de construção do conhecimento e os desafios do ensino-aprendizagem. Revista online de Política e Gestão Educacional, v.22, n.1, p. 410-423, 2018.

MAY, T. Pesquisa social: questões, métodos e processos. 3. ed. Porto Alegre: Artmed, 2004.

NOBRE, R.; MORAES, F. A contribuição do estágio supervisionado para a construção dos saberes docentes. IN: Anais do XII Congresso Nacional de Educação. 2015.

PIAGET, J. Biologia e Conhecimento. 2ª Ed. Vozes: Petrópolis, 1996.

PIMENTA, S. G.; LIMA, M, S. Estágio e docência. 6. Ed. São Paulo: Cortez, 2011. . GARRIDO, S. O estágio na formação de professores: unidade teórica e prática? 3. ed. São Paulo: Cortez, 2005.

. S. G. O estágio na formação de professores: unidade teórica e prática? 3. ed. São Paulo: Cortez, 2005.

S. G. Formação de professores: saberes da docência e identidade do professor. Revista da Faculdade de Educação, v. 22, n. 2, p. 72-89, 1996.

PIMENTA, S. G. (org.). Saberes pedagógicos e atividade docente. São Paulo: Cortez: 1999.

REUL, M. A.; LIMA, E. D.; IRINEU, K. N.; LUCAS, R. S. C. C.; COSTA, E. M. M. B.; MADRUGA, R. C. R. Metodologias ativas de ensino aprendizagem na graduação em odontologia e a contribuição da monitoria - relato de experiência. Revista da ABENO, v.16, n. 2, p. 62-68, 2016. 
ROSSATO, M.; MATOS, J. F.; PAULA, R. M. A subjetividade do professor e sua expressão nas ações e relações pedagógicas. Educação em Revista, n.34, e169376, DOI: http://dx.doi.org/10.1590/0102-4698169376, 2018.

SILVA, K. Currículo, gênero e identidade na formação de professores/as. Dissertação (Mestrado em Educação) - Faculdade de Educação, Universidade Federal de Juiz de Fora, Juiz de Fora, MG,195 f., 2011.

ZABALZA, M. O ensino universitário: seu cenário e seus protagonistas. Porto Alegre: Artmed, 2004.

\section{APÊNDICE - FIGURAS EM INGLÊS}

Figure 1. Average age of the survey participants

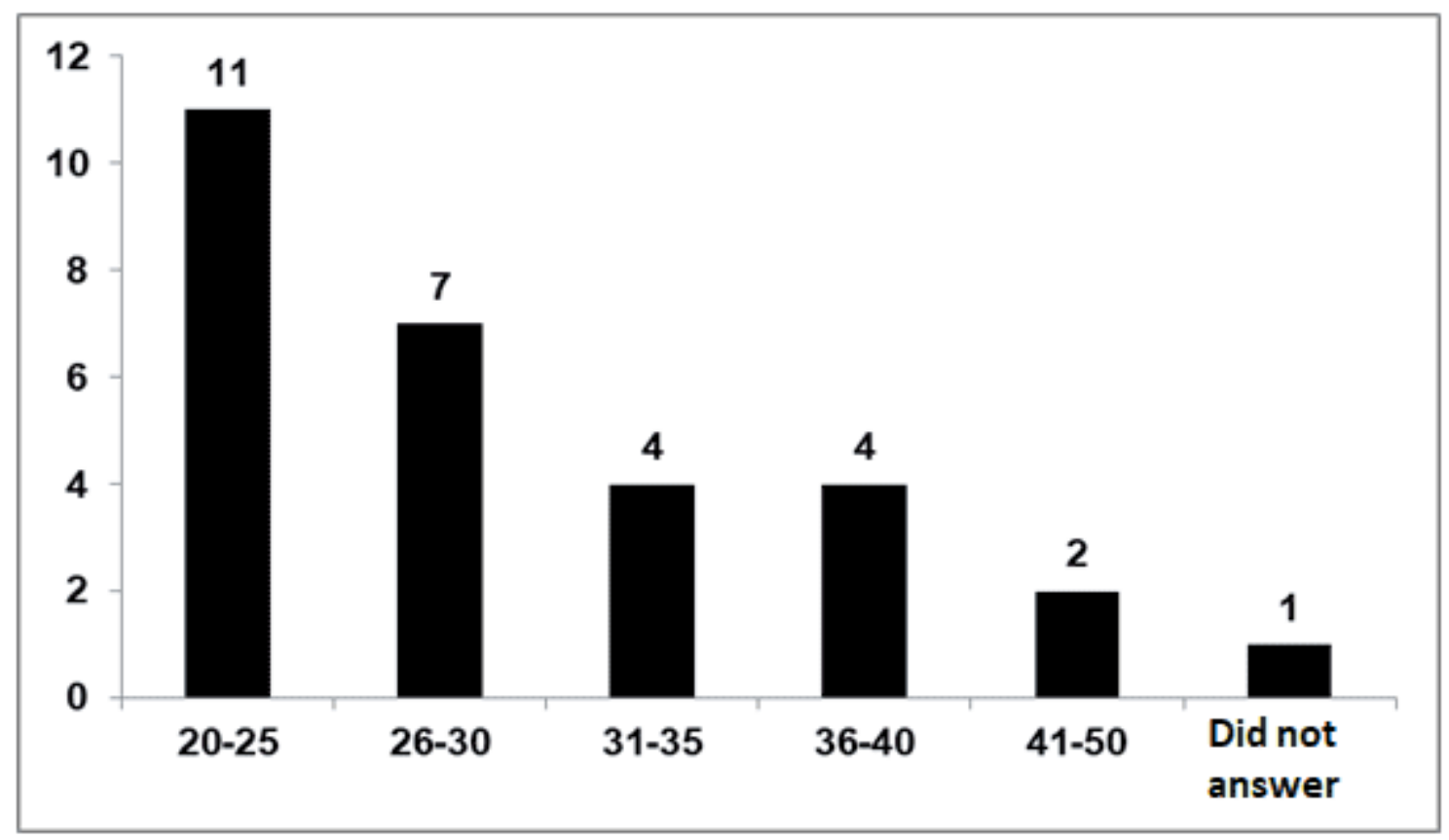

Source: Authors, 2019. 
Figure 2. Distribution of total research participants by sex

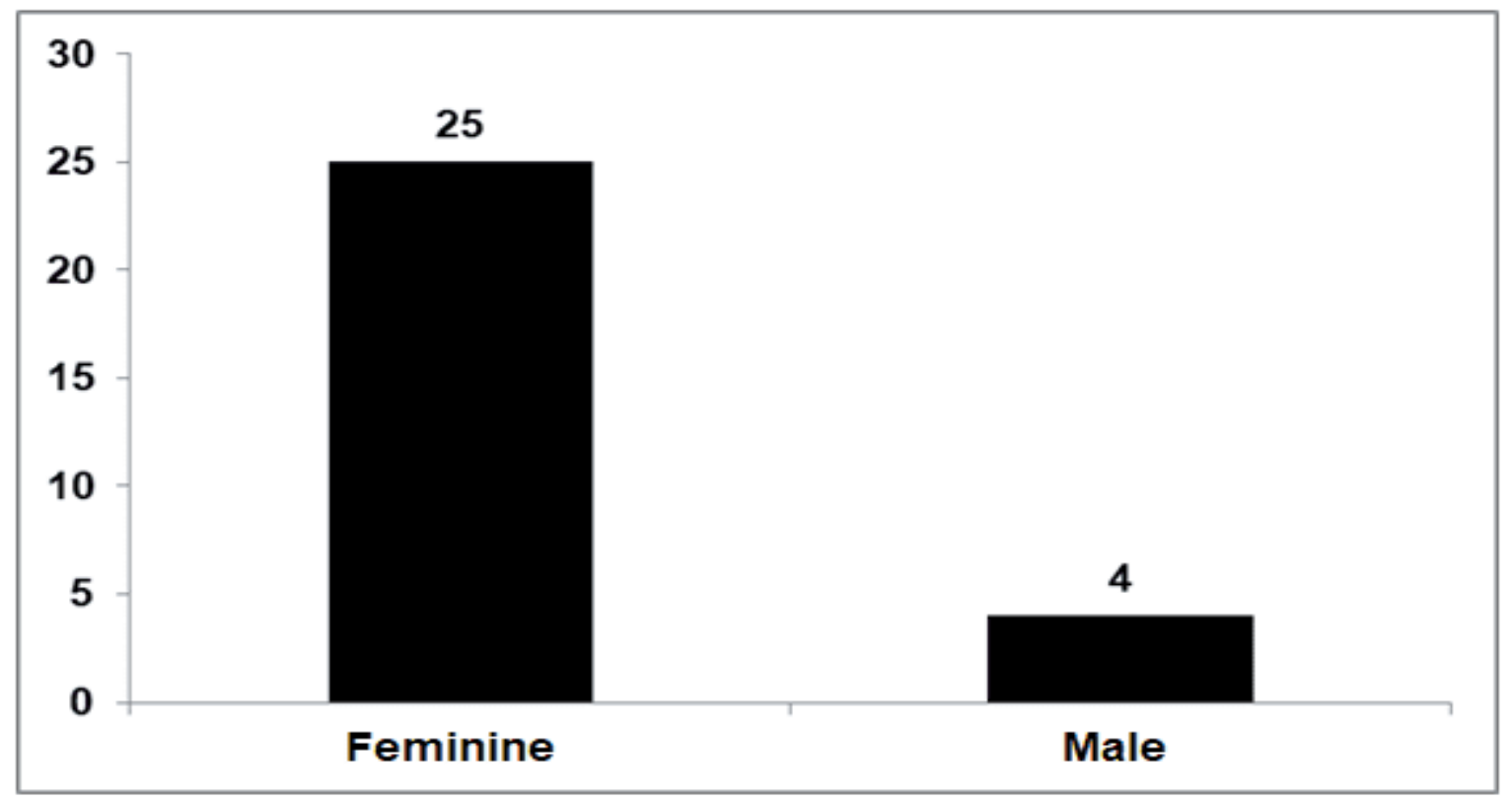

Source: Authors, 2019.

Figure 3. Distribution of total survey participants by city

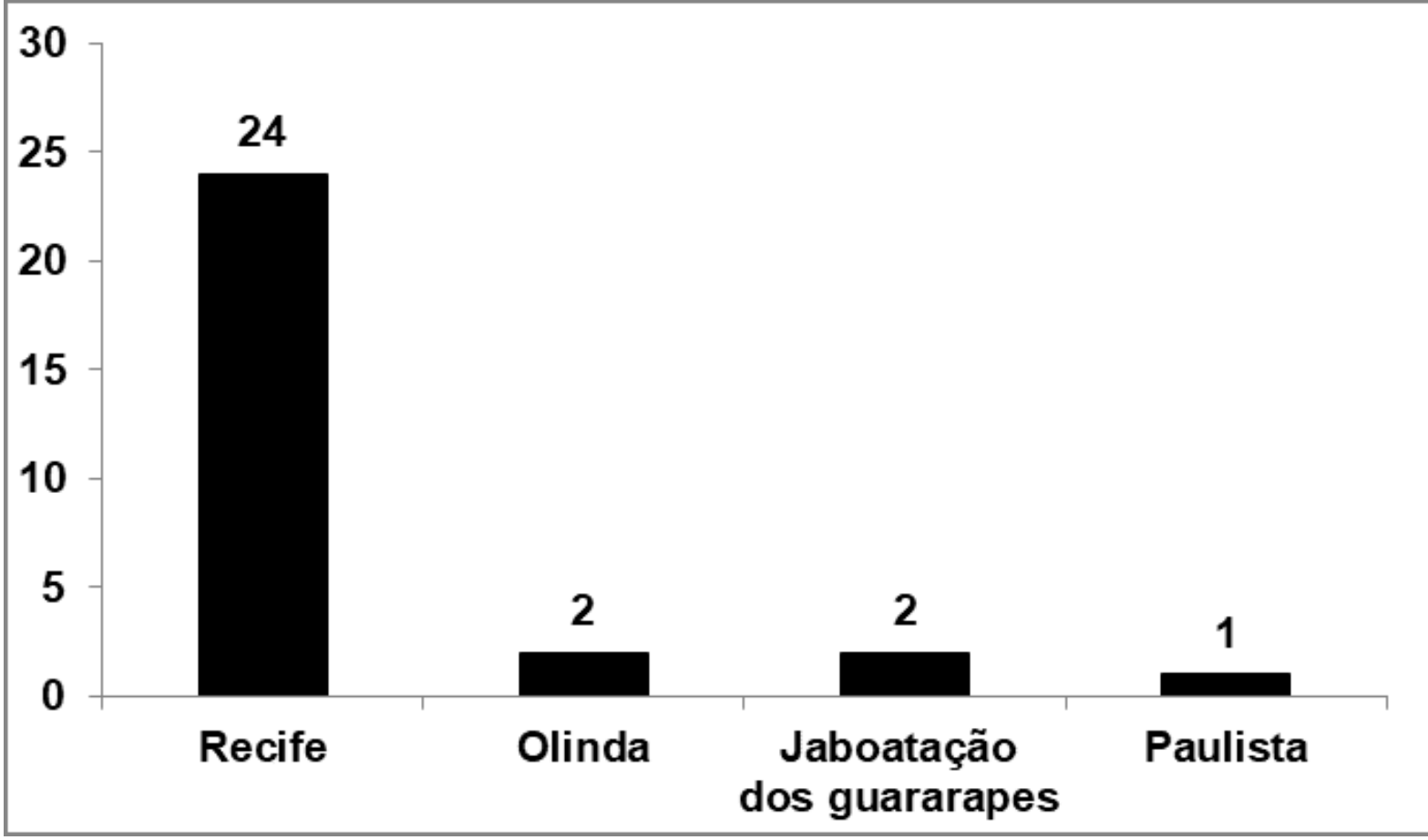

Source: Authors, 2019. 
Figure 4. Percentage of the course period, in which the research participants were currently attending

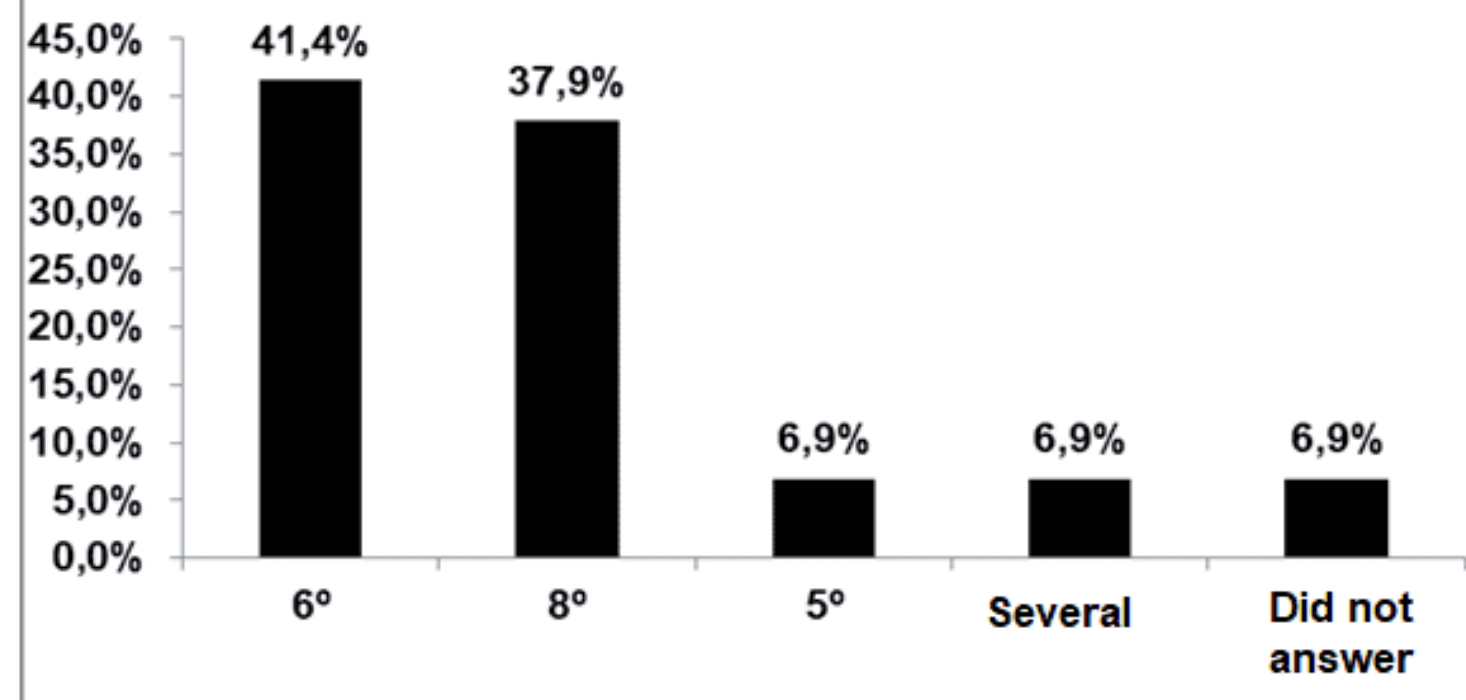

Source: Authors, 2019.

Figure 5. Percentage of responses when asked if the theoretical knowledge of the classroom is related to the reality of today's society

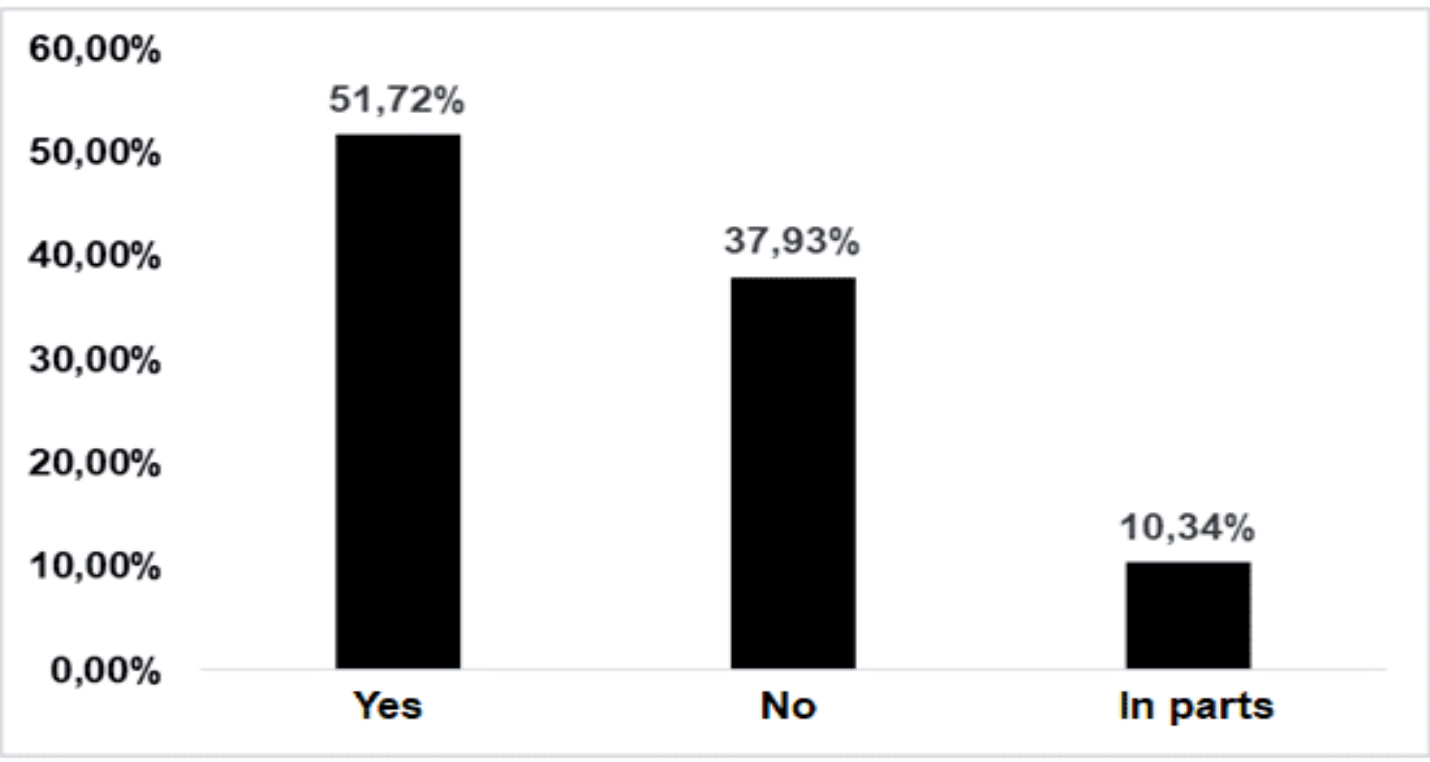

Source: Authors, 2019. 
Figure 6. Percentage of unanswered questions

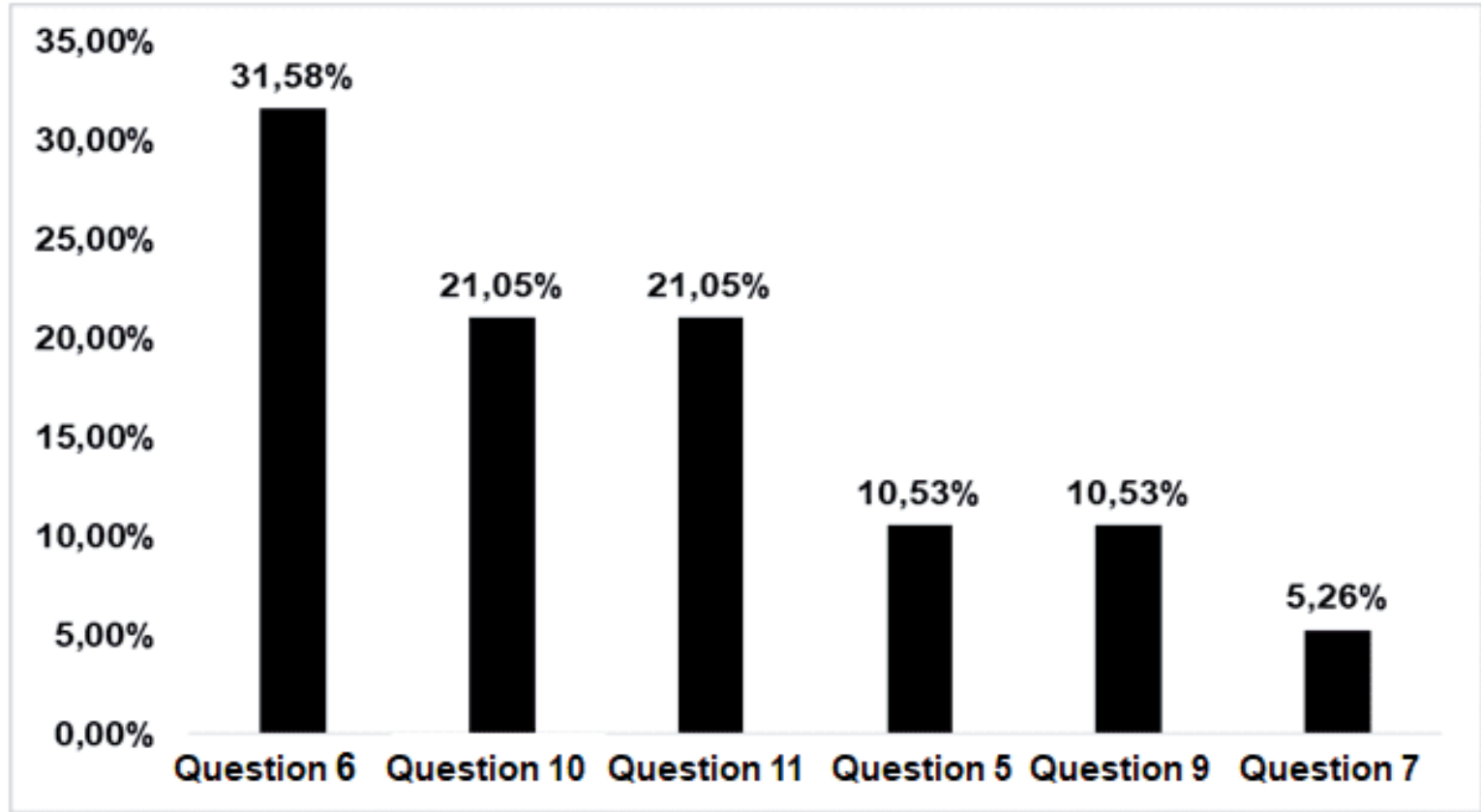

Source: Authors, 2019.

Enviado: Abril, 2020.

Aprovado: Agosto, 2020. 